\title{
Between Handholding and Hand-held Devices: Marketing Through Smartphone Innovation and Women's Entrepreneurship in Post Conflict Economies in Times of Crisis
}

\author{
Nisreen Ameen ${ }^{1}$ (I) $\cdot$ Nnamdi O. Madichie ${ }^{2} \cdot$ Amitabh Anand $^{3}$ \\ Accepted: 30 August 2021 / Published online: 15 September 2021 \\ (C) The Author(s), under exclusive licence to Springer Science+Business Media, LLC, part of Springer Nature 2021
}

\begin{abstract}
There is a wide gender gap in developing countries due to a range of cultural, economic and political barriers. This is even more accentuated in post conflict economies in times of crisis. Smartphones and mobile applications can help to narrow this gap. The economic and non-economic challenges facing women entrepreneurs and the role of smartphone innovation in overcoming these challenges and developing strong marketing strategies were investigated. We drew on the $5 \mathrm{M}$ model to investigate how mobile applications can support women entrepreneurs. We conducted thirty interviews with women entrepreneurs in Iraq. The findings show that mobile applications provided these entrepreneurs with innovative ways to overcome many of the challenges they face in relation to running a business. The research provides theoretical contributions by developing an integrated, multilevel analytical model on women in entrepreneurship based on extending the $5 \mathrm{M}$ model with new technology-related elements. Practical, policy and managerial implications are discussed.
\end{abstract}

Keywords Smartphone $\cdot$ Innovation $\cdot 5 \mathrm{M}$ model $\cdot$ Women entrepreneurs $\cdot$ Women's empowerment $\cdot$ Mobile marketing

\section{Introduction}

The role of information and communication technologies (ICTs) in fostering the development of 'developing' countries is still the subject of debate (Sein et al., 2019). Specifically, academics have debated the types of development to which ICTs can contribute and whether the outcomes are always positive (Chew et al., 2015; Tam et al., 2020; Anand et al., 2021). Previous studies have emphasised that ICTs are important for development (Wheadon \& Duval-Couetil, 2018; Ameen \& Willis, 2018a). For example, they have found that smartphones and mobile applications can support entrepreneurs in the Middle East (Alderete, 2017; Madichie, 2011). Given the emergence of the digital economy, they are key to

Nisreen Ameen

nisreen.ameen@rhul.ac.uk

Nnamdi O. Madichie

nnamdi.madichie@bil.ac.uk

Royal Holloway, University of LondonLondon, UK

Bloomsbury Institute, London, UK

3 Excelia Business School, CERIIM, La Rochelle, France entrepreneurs' ability to start up and develop a business and exploit new opportunities, which, in turn, contributes to local and regional economic development (Alderete, 2017). The benefits extend well beyond economic outcomes, especially among women in the Middle East (Ameen \& Willis, 2016). Previous studies have called for a more holistic view of how ICTs can foster development and gender equality (Walsham, 2017; Sein et al., 2019).

The COVID-19 pandemic rattled businesses worldwide, mainly micro, small, and medium-sized enterprises (MSMEs) (Shashidhar, 2021). It has created three significant challenges for female entrepreneurs. First, the economic downturn is disproportionately affecting the industries in which the majority of women work. Second, women are more likely to run many of the youngest, smallest, and most vulnerable businesses. Third, with schools closed and elderly family members in danger, women are more likely to juggle primary caregiving and homemaking while scrambling to save their businesses. The prospects are daunting, and women have few options (Manolova et al., 2020).

COVID-19 has seen a spurt of women entrepreneurs in developing economies such as India where post COVID digitalisation has accelerated (Akwo et al., 2020). Entrepreneurs are already feeling the adverse effects of the COVID-19 crisis. While many entrepreneurs in the Middle 
East and North Africa (MENA) are men, women-owned businesses are likely to be especially susceptible to forced closures and lost revenue due to extended closures. Specific countries have already reported a high proportion of women-owned SMEs closing their doors because of the crisis (UFM [Union for the Mediterranean], 2020). Unfavourable business conditions will unfairly target smaller businesses, which have lower economies of scale and higher costs of doing business. However, the widespread use of smartphones in developing countries and the decreasing cost of internet services have created unprecedented opportunities for individuals to leverage these technologies to start and grow businesses (Martinez \& Nguyen, 2014; Choudrie et al., 2020).

Particularly, the COVID-19 crisis in post conflict economies reflect increased complexities (Eufemia et al., 2020). Although some scholars emphasised that many possibilities exist for people to exploit post-conflict economy (Brück et al., 2013). McMillan and Woodruff (2002) note, that most people underestimated the significance of entrepreneurship, possibly because of a sense that setting up a business, risky anywhere, is especially risky in an economy undergoing deep reform. Studies focusing on the capacity for entrepreneurship innovation and development are still lacking in a post-conflict society. A post conflict and developing economy like Iraq, lacks innovators and entrepreneurs, even though there are opportunities for these people to thrive and make changes. Therefore, further investigation into Iraq's local markets and national economy are critical to better understand how entrepreneurship will play a role in the country's recovery (Brück et al., 2013). Furthermore, employing qualitative methods (e.g., interviews or case studies) could play a substantial role in understanding entrepreneurship in regions like Iraq (Aldairany et al., 2018). Conducting semi-structured interviews can provide a higher level of generalisability of the results in comparison to case studies. In addition, semi-structured interviews allow for open-ended responses from participants for more in-depth information.

A recent review of the literature on technology and women's entrepreneurship identified the need for more integrated, multilevel analytical frameworks in research on women's use of technology in entrepreneurship (Wheadon \& Duval-Couetil, 2018). Instead of focusing on women's lack of resources, researchers need to develop broader theoretical frameworks to understand how technology can overcome the layered barriers to access and participation (Wheadon \& Duval-Couetil, 2018). Compared with women in developed countries, women in developing countries face a larger number of non-economic challenges and barriers to starting and running a business (Brush \& Cooper, 2012). This is acknowledged in recent studies which also highlight the need to be more specific about the types of empowerment that ICT for development (ICT4D) can create (Pandey \& Zheng, 2019; Pal \& Herath, 2020; Elena-Bucea et al., 2020). Hence, it is important to explore the challenges facing women's entrepreneurship in developing countries and the ways in which smartphones can contribute to the human, economic and social development of women entrepreneurs, their families and their societies.

Therefore, this study investigates the challenges facing women entrepreneurs from a developing economy perspective and the role of mobile technology in overcoming these challenges, taking a sample of Iraqi women entrepreneurs. in doing so, we adopt the lens of the $5 \mathrm{M}$ model proposed by Brush et al. (2009). The research attempts to answer the following question: What are the challenges facing women entrepreneurs in post-conflict economies and how can smartphones and mobile applications contribute to overcoming these challenges and enabling marketing through smartphone innovation?

This research goes beyond economic outcomes to explore the additional outcomes of smartphone and mobile application use among women entrepreneurs in a developing country. Hence, this study bridges a gap in ICT4D research, which has focused mainly on the associated economic growth (Chew et al., 2015; Sein et al., 2019; Pandey \& Zheng, 2019). The $5 \mathrm{M}$ model, developed by Brush et al. (2009), is commonly used to identify factors that determine the success or failure of women's entrepreneurship. This comprehensive model captures the main factors that influence women's entrepreneurship, within and beyond the business context. This study extends the $5 \mathrm{M}$ model to investigate how mobile applications can support women entrepreneurs.

The gender gap in Iraq is wide due to several cultural, economic and political barriers (Ameen \& Willis, 2018b). These barriers hinder women from running successful businesses and becoming economically independent. This is a major problem, especially considering that women constitute almost half (49\%) of the population in Iraq (Trading Economics, 2016) and many of them have become heads of households due to wars (UNDP, 2012). In addition, $80 \%$ of these female heads of households are widows, divorced, separated, or caring for sick spouses (Vilardo \& Bittar, 2018). Therefore, it can be argued that the case of women's entrepreneurship in Iraq is unique, hence making it imperative to investigate how smartphone innovations can help this group become more successful, independent and empowered. This study makes several contributions to existing knowledge. First, it extends knowledge in the area of ICT4D by focusing on a wider range of development outcomes of smartphone and mobile application use among women entrepreneurs in developing countries. Second, it draws on the $5 \mathrm{M}$ model (Brush et al., 2009) to investigate the significance of the role of smartphones and mobile applications in developing women's entrepreneurship in the context of Iraq. This bridges a gap in research on the use of smartphones and mobile applications. The study highlights how mobile technology can help women 
entrepreneurs overcome some of the challenges identified in the $5 \mathrm{M}$ model (i.e., management, money, market, meso and macro factors, and motherhood). Furthermore, the study has implications for a range of stakeholders including policymakers, mobile companies, mobile application developers, banks and financial institutions in post-conflict economies. Hence, our study advances the views expressed by scholars who emphasised the need to study entrepreneurship in post conflict economies (e.g., Aldairany et al., 2018; Brück et al., 2013). This is the first study to provide a holistic synthesis of the challenges facing women entrepreneurs in a country of high risk of instability and a post conflict economy (i.e., Iraq). The study offers managerial implications for government bodies and policy makers.

The next section provides a review of the related literature. This is followed by the methodology and results. We then provide a discussion of the results, followed by the theoretical contributions, managerial implications and limitations and future work. Finally, we provide a conclusion for the study.

\section{Literature Review}

\subsection{Women's Entrepreneurship, ICT4D and Smartphones}

Although women need to earn money and generate income for their families, they find themselves under pressure when it comes to balancing work with family life (Al-Dajani \& Marlow, 2010; Ward, 2007). How women entrepreneurs balance family and business life in developing countries (more specifically, in the Middle East) is under-researched (Al-Dajani \& Marlow, 2010). The role of culture cannot be neglected when studying entrepreneurship (Mazawi, 2002). In Arab countries, including Iraq, mainstream culture does not support women entrepreneurs (Ahmad, 2011). Furthermore, previous studies in Arab countries have demonstrated that one of the main reasons Arab women become entrepreneurs is that it is difficult for them to find employment (Jamali, 2009). Women's employment in Iraq can also be viewed through the lens of patriarchy. Hartmann (2001, p. 14) defines patriarchy as "relations between men, which have a material base, and which, though hierarchical, establish or create interdependence and solidarity among men that enable them to dominate women". Therefore, men have control over women's labour power, and they are dominant in the household and in society (Sultana, 2012). The attitude towards expatriate women in business in Iraq remains conservative (Expat Arrivals, 2017).

Compared with women in other Arab countries, Iraqi women have restricted mobility and limited access to products and services, and they are less likely to participate in economic activities (International Rescue Committee, 2014). Being in contact with men while running a business has become a major concern for Iraqi women in recent years (International Rescue Committee, 2014). In part, this is due to sexual harassment, a lack of security and gender-based violence. Gender-based violence has serious implications for women's entrepreneurship (Vossenberg, 2013). This issue is particularly pressing in Iraq because of the lack of policies, regulations and services that support women entrepreneurs and the absence of public support for women's security (Ceasefire Centre, 2015). In addition, women are encouraged to work in the public sector, which is viewed as offering them better protection than the private sector (Alhabidi, 2013). Iraqi women who run small- or medium-sized enterprises (SMEs) may face even more barriers than women in other Arab countries do. These additional barriers are due to war and the unstable economic situation. According to the World Bank (2016), Iraq has the seventh-highest number of legally enacted and economically measured gender inequalities. The rate of participation in the labour force for women aged 15-24 is $8 \%$, while the corresponding rate for men in this age group is $48 \%$ (World Bank, 2016). The economic participation of women in Iraq is among the lowest in the world, as only $8 \%$ of them are working, $13 \%$ are in the labor market and less than $1 \%$ work in decision making positions (Faraj, 2020). Hence, promoting women's entrepreneurship in Iraq would provide benefits on two levels: microeconomic, ensuring women's financial security and economic independence; and macroeconomic, enabling women to contribute to the family income and the Iraqi economy. For example, Fatin Al-Wali, founder of the "escape the room" initiative in Iraq, states that for women in Iraq, "There is also the struggle of balancing business and a family life when you have children, like myself. We face difficulties when it comes to flexible working hours, kids' utilities in work places, and the ability to find a support system" (Baur, 2018). Therefore, it is important to identify the entrepreneurship challenges that these women face and find innovative ways to enable them to be successful.

In a cross-national study in Ghana, Kenya and Uganda, Bailur and Masiero (2017) found that affordable mobile Internet services may not lead directly to income generation and that there are some constraints in these countries, such as a lack of knowledge of how to use smartphones. In addition, the need for training in using mobile applications has been highlighted by Rajan and Jayashri (2017). Given that VoIP applications are the most frequently used by entrepreneurs in some African countries (Boateng, 2017), the affordability of the mobile Internet is important. This issue is applicable to the case to the case of Iraq too.

The benefits of using smartphones as tools for economic development are reasonably well established in the existing literature on ICT4D (Donner \& Escobari, 2010). Using ICTs can bring economic benefits to women, their families and wider society (Ameen \& Willis, 2018b; Ameen et al., 2018a). However, the benefits of using ICTs (including 
mobile technologies) extend beyond economic development; for example, they can contribute to social development by reducing structural inequalities (Chew et al., 2015). In addition, using ICTs, more specifically smartphones may have positive outcomes for health, education and standards of living (Hashem, 2015; Wolff-Piggott et al., 2018; Uchida et al., 2020; Pal et al., 2020; Albashrawi \& Motiwall, 2019; Albashrawi et al., 2019; Ameen et al., 2018b). ICTs can also be used as tools to empower women and enable them to overcome discrimination, inequality and poverty and to connect with the outside world (Yeo \& Grant, 2017). In addition, smartphones can provide various solutions to improve marketing activities and strategies. For example, using social media platforms such as Facebook, Twitter, Instagram, and LinkedIn, which are popular in the Middle East, can lead to the following advantages: business growth (via growth in sales); profit; increased employment; increased market share (Berger \& Kuckertz, 2016), a better brand image; improved customer relationship management, increased message reach, fewer contact costs and enhanced customer loyalty (Melumad $\&$ Meyer, 2020).

In particular, smartphones can enhance women's psychological well-being by increasing their financial security, connections and independence (Bhavnani et al., 2008). In addition, the increased communication enabled by smartphones can strengthen family ties. A smartphone does not necessarily enhance women's status in their communities (Walsham, 2017). Nevertheless, O'Donnell and Sweetman (2018) explain that in order to understand how ICTs can help women achieve equality in all countries and can empower women who are living challenging lives in difficult contexts, more research in the field of ICT4D is needed. Technology can be an enabler for human activities; therefore, focusing on this area of research draws on a wide variety of topics (O'Donnell \& Sweetman, 2018). Table 1 provides examples of recent studies on mobile technology and women's entrepreneurship. Despite the presence of studies on the benefits of smartphones in empowering women, there is little understanding of the non-economic development outcomes of smartphone and mobile application use among women entrepreneurs in unstable developing countries; in particular, post-conflict economies with male-oriented hierarchies and values, where women face constraints that go beyond financial limitations.

Smartphones have much potential for placing women in low-income countries on a higher economic trajectory (Newell, 2011). Kapinga et al. (2016) explain that using smartphones can enhance women entrepreneurs' businesses by reducing search costs; increasing market efficiency; promptly communicating business information; and improving productivity through better supply-chain management.
However, Komunte (2015) explains that there is no theoretical foundation for how women use ICTs, including smartphones. Nevertheless, smartphones have a positive impact on women's entrepreneurial activities by increasing economic growth, knowledge and self-esteem (Mackey, 2012).

\subsection{The 5M Model}

Previous studies have identified challenges and success factors related to women's entrepreneurship, mainly in developed countries. Bates et al. (2007) developed a theoretical framework for entrepreneurship, the 3Ms: market (encapsulating opportunity), money (internal and external funds) and management (in the form of human and organisational capital). Entry and survival in the market requires money and management, which is shown by the bottom two circles. However, Brush et al. (2009) argue that it is difficult to separate successful entrepreneurship from the entrepreneur's external environment, especially in the case of women (Carter et al., 2001). Therefore, the authors extended the $3 \mathrm{M}$ framework by incorporating aspects that acknowledge the environment surrounding women entrepreneurs. The resulting $5 \mathrm{M}$ model includes two additional factors: motherhood (the family and household context); and the meso/macro environment. The "meso" aspect includes regional support policies, services and initiatives, while the "macro" aspect includes national policies, strategies, cultural and economic influences. Brush et al. (2009) explained that there are overlapping boundaries and interdependencies between the elements of the $5 \mathrm{M}$ model. Motherhood plays a central role in the model as it acts as a mediator between the market, management, and money elements. The macro level social norms and gender socialisation could mediate motherhood by conditioning the household division of labour. In addition, there is an overlap between the macro and "motherhood" issues as the family and household contexts link to the cultural and economic influences. Furthermore, the meso environment (support policies, services, and initiatives) concerns the intermediate structures/ institutions between the macro society-the economy-wide lev$\mathrm{el}$ and the micro level. In fact, the mediating institutions at the meso environment level could impact any of the other four $\mathrm{M}$ facets. The household and family context of female entrepreneurs; and the meso/macro environment which captures considerations beyond the market, such as expectations of society and cultural norms (macro), intermediate structures and institutions (meso) (Brush et al., 2009). Many studies have used and extended the model in the context of entrepreneurship (e.g., Iakovleva et al., 2013; Welsh et al., 2014; Pergelova et al., 2018). The framework provides evidence that, for women, successful entrepreneurship depends on not only their abilities but also their surrounding environment. Thus, entrepreneurship is socially embedded. This view is supported by 


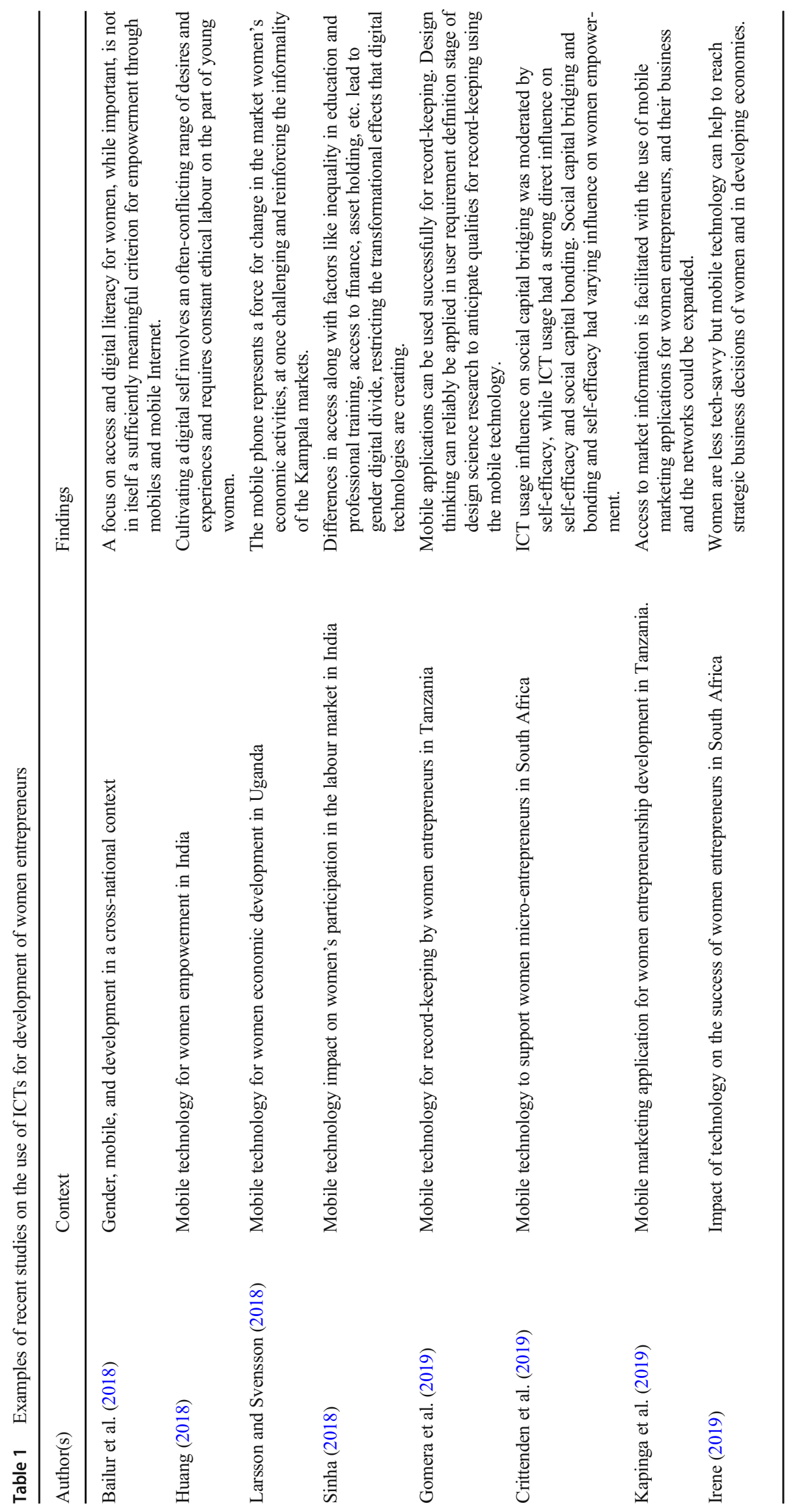


many studies on women's entrepreneurship (e.g., Carter et al., 2001; Kazemi, 2000; Stead, 2017). However, given the impact of technology on personal life and business today (Ghahramani \& Wang, 2019), it can be argued that theories on women's entrepreneurship, including the $5 \mathrm{M}$ model, should integrate technological factors as significant determinants of success or failure. This is especially the case for women entrepreneurs, as previous studies have emphasised the role of technology in empowering women (Ameen \& Willis, 2018b).

The $5 \mathrm{M}$ model developed by Brush et al. (2009) was adopted in this research due several reasons. First, it is one of the pioneering models in the area of entrepreneurship as it acknowledges the distinctiveness of female entrepreneurship. Second, the research emphasises the role of the environment surrounding female entrepreneurs at both the macro and micro level and the complex systems such as new venture creation (Berger \& Kuckertz, 2016). The $5 \mathrm{M}$ model acknowledges the internal and external factors that can affect women entrepreneurship. Given that this research focuses on female entrepreneurs and the external environment surrounding them, the use of this model is justified. Third, from a theoretical perspective, despite that the $5 \mathrm{M}$ model has been used in previous studies (e.g., Berger \& Kuckertz, 2016; Welsh et al., 2018; Tahir \& Baradie, 2019), none of these studies examined how technology can play a significant role in the development of women's entrepreneurship in the context of this model in a developing country such as Iraq. Studying the impact of technology (smartphones and mobile applications) as an external factor, in addition to the factors integrated in the $5 \mathrm{M}$ model provides a better understanding of women's entrepreneurship. The model captures the main factors related to women entrepreneurship and the main challenges they face when starting their own business. In addition, the model has not previously been studied from the perspective of the use of mobile applications by women entrepreneurs. This is the first study that uses and extends the $5 \mathrm{M}$ model to investigate how mobile applications can support women entrepreneurs.

While previous research has emphasised the importance of smartphones for supporting women entrepreneurs, there has been no holistic synthesis of the challenges women face and how modern mobile technologies can help to overcome those barriers to economic, social and human development. This gap has been identified in previous studies (Bailur \& Masiero, 2017; Komunte, 2015; Mackey, 2012). Using the $5 \mathrm{M}$ model to investigate these challenges, and how women entrepreneurs can overcome them by using smartphones and mobile applications, provides a better understanding of the economic, social and human development outcomes of using these devices.

\section{Methodology}

Qualitative research enables researchers to gain insight into people's emotions and thoughts (Sutton \& Austin, 2015). We drew from the epistemological tradition, which entailed adopting a lifeworld ontology that all observations are valueand theory-laden and that investigations of the social world cannot uncover objective truth (Tlaiss \& Kauser, 2019). The qualitative method was appropriate for achieving a deep understanding of how smartphones and mobile applications can help Iraqi women entrepreneurs to overcome the social, family, cultural, market and financial barriers in a complex society. While collecting data, we used an exploratory approach and several grounded theory precepts (Glaser \& Strauss, 2017) to identify distinct patterns. Research relying on qualitative data is common for providing rich and in-depth data (Davies et al., 2018; Eisenhardt \& Graebner, 2007). Such an approach has been used in previous studies on ICT4D (e.g., Baro \& Endouware, 2013; Nuseibeh et al., 2017). Charmaz (2014) contends that research seeking theoretical understanding employs inductive logic, takes data through rigorous comparative analysis, purports to incite the emergence of theory, and seeks to integrate theory with policy and practice. We used semi-structured interviews with a sample of women entrepreneurs in Iraq. Using semi-structured interviews enabled us to investigate the barriers these women face and how using smartphone and mobile applications has helped them to overcome these challenges.

A qualitative research approach was also appropriate due to the lack of research on ICT4D among women entrepreneurs in Iraq, particularly the non-economic development outcomes. We intended to carry out an exploratory study that fit with a discovery-oriented methodology (Mahrer, 1988). This enabled us to obtain rich data that provided an initial in-depth understanding of how smartphones and mobile applications can contribute to the social, economic and human development of women entrepreneurs in Iraq. Research relying on qualitative data is common for providing rich and in-depth data (Davies et al., 2018; Eisenhardt \& Graebner, 2007).

The participants were approached by the authors through social media and invited them to take part in a Skype interview. Thirty-five women were invited to participate, but due to access issues (such as time, availability on Skype etc.) only thirty interviews were conducted. We conducted the interviews via Skype. Purposive sampling was used because it has the potential to provide us with a wealth of information (Neuman, 1997) through the selection of information-dense cases that can yield insights and a deeper understanding (Patton, 2002). Additionally, we sought to locate women who were available, willing to participate, and capable of providing information via Skype through use of their smartphones. In addition, it allowed us to save time while collecting the data and it was more convenient for the participants as the interviews were arranged at the time that suits them the most. 
Charmaz (2014) emphasised the difficulties inherent in conducting interviews in diverse cultural communities, where recording or taking notes may be prohibited. This was not the case in our research, as consent from participants was obtained prior to recording the interviews. Our criteria for inclusion were as follows:

(1) participants must be at least 18 years old.

(2) participants must have owned a small businesses for at least one year.

(3) participants must live in Baghdad, the capital of Iraq, where there are more opportunities for entrepreneurial activities; and

(4) participants must own a smartphone and use mobile applications.

Since no lists or directories of women entrepreneurs in Iraq were found as in case of other Middle eastern countries such as UAE, the participants for our study were selected through personal contacts, references and others through their social media accounts and those contacted gave additional references of others - who would be willing to participate in our interview.

Each interview lasted for approximately $30 \mathrm{~min}$. The interviews were conducted in Arabic and was transcribed into English. The collected data were analysed using NVivo analysis software (Ishak \& Bakar, 2012). Corbin and Strauss (2008) explain saturation as the situation when no new categories or relevant themes are emerging. We believe that we reached the point of data saturation or theoretical saturation, as new data did not add new insights and we faced data replication and redundancy. According to Pandit (1996), theoretical saturation is met when the marginal value of new data is minimal. In this research, we noticed that codes in the data started to repeat. Hence, we reached the point of theoretical saturation as no new and relevant data created any new categories. We used the software to identify themes from the data to understand the barriers to women's entrepreneurship. We then grouped the themes into categories using open coding, as recommended by Strauss (1990). We analysed the coded data and compared them with pertinent concepts in the extant literature, and considered relevant patterns emerging from the data. Then, we used axial coding to identify relationships between the benefits of using mobile applications and the challenges these women face. Axial coding involves identifying relationships among open codes. By exploring the relationships within categories and making connections between them, we merged, split, clustered and refined these in line with guidance from Strauss (1990).

\section{Results}

In reporting the main findings of the study, we categorised the participants by their education level, which ranged from high school to master's degree. The participants owned different types of businesses: seven owned a retail outlet, four owned a fashion retail business, three owned a supermarket, two owned a training centre, two owned a language centre, two owned a pharmacy, two owned a wedding decor business, one owned a nursery, one owned a designer warehouse, one owned a bakery, one owned a catering business, one owned a furniture store, and one owned a learning centre. Table 2 is organised by the source of funding the women used to start a business. The participants were between 26 and 50 years old. There were three main sources of funding: selling personal belongings; personal loans from family; and family savings. Out of the thirty interviewees, nine acquired a personal loan from family, fifteen sold personal belongings and six used family savings. Thirteen participants were married, fifteen were single and two were widows. All the participants owned a smartphone, which indicates the tech savviness. Eight participants used an iPhone, ten used a Samsung, five used a Lenovo, three used a Huawei and four used an HTC. One of the inclusion criteria in the purposive sampling method was that the smartphones had to be smartphones capable of multiple functionalities that could support mobile commerce activity. The participants had been using smartphones for between five and fourteen years. They had between one and ten years of experience in running a business. The participants owned different types of businesses, and they were all the sole owners of their businesses. All participants and their businesses were located in the city of Baghdad and in urban areas. All participants agreed that their annual turnover was under $\$ 30,000$ a year.

In the following subsection, we present the findings on the challenges faced by women entrepreneurs in Iraq with reference to the $5 \mathrm{M}$ model facets, in addition to mobile technology as a sixth element which overlaps with all other facets of the model. We then explore how using smartphones and mobile applications can support these women.

\subsection{Challenges Faced by Women Entrepreneurs}

\subsubsection{The Need for Supporting Policies for Women Entrepreneurs (Meso Factors)}

Most of the participants stated that the government and policymakers need to be more aware of the importance of supporting more Iraqi women to become entrepreneurs, especially those who are sole breadwinners. Most of them expressed a strong desire for policies that support women (especially women entrepreneurs) and specify and protect women's rights. One respondent, who was aged 35, single, educated to high school level and owned a catering business, stated: 


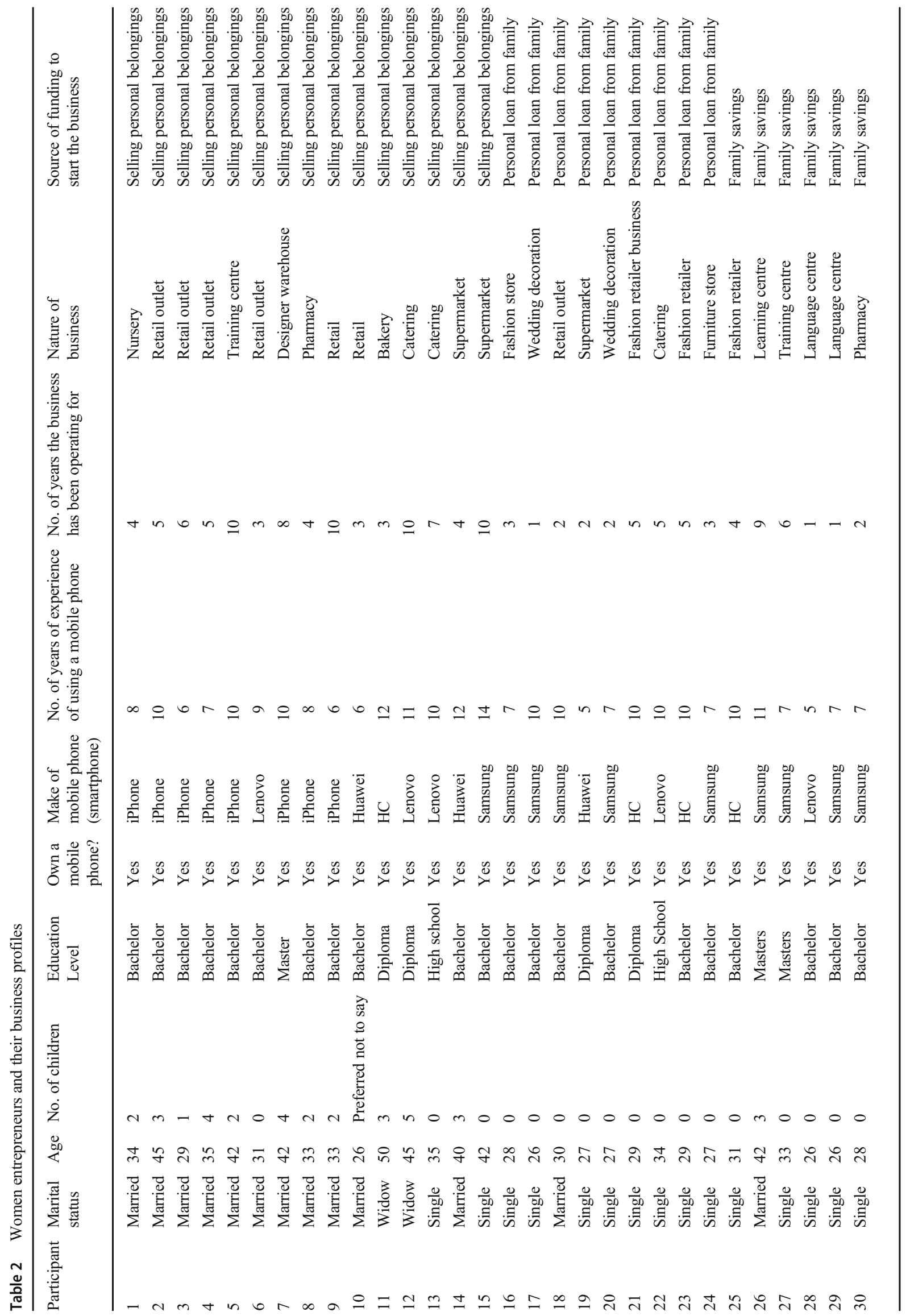


Personally, I think the government should work on ensuring that these services are available to women. (Participant 13)

Another respondent, who was aged 34, single, educated to high school level and owned a catering business, stated:

The services are not currently available in Iraq and if they are then it is very rare ... the government had an initiative to use the mobile banking facility for people. However, the project stopped three years ago and we never heard about it again but if we are offered these services, we can use mobile applications a lot more. (Participant 22).

This indicates an overlapping relationship between the meso factors and money as found in the $5 \mathrm{M}$ model (Brush et al., 2009). The participants also explained that security is needed, both physically and online. Mobile cyber-security tools are needed to protect women and their businesses when using mobile applications. For example, one participant, who was aged 29, married with one child and owned a retail outlet, stated:

It will be helpful in terms of increasing my physical security and reaching as many customers as possible. I have some issues like, for example, despite that ensuring my physical security is important and can be enabled with the use of smartphones, I would still have the issue of mobile security, so there are some applications that would allow locating where my mobile is or where I am located ... There should be some policies related to this. (Participant 3)

This shows a link between the meso and macro factors as according to the participants' views, there is a need for government support and policies which are part of the meso environment to enhance their safety and security which are part of the macro environment. This confirms the findings of previous studies on the relationship between meso and macro factors (e.g., Brush et al., 2009; Bastian et al., 2018). The participants indicated that government initiatives to support and protect mobile money and its use are needed so that they can rely on their smartphones and applications to run their businesses.

\subsubsection{Lack of Funding (Money)}

When the participants were asked how they were able to obtain the necessary funds to start a business, they explained that they borrowed the money from their family, sold valuables or used family savings. No loans were available to them from banks or other institutions. A participant described how she financed her business as follows:

I knew that funding would not be available for me to use if I decided to start my own business so while I was planning the business, I was planning how to fund it and I sold some personal belongings. This restricted me in terms of how to build the business, as I was very restricted with the budget. (Participant 3)

Another respondent, who aged 50, a widow, educated to diploma level and owned a bakery business, stated:

I had to start from zero. I had to borrow money, obviously there is nothing for females in my situation, so it was very difficult at the beginning, especially in terms of finance ... so the only option for me was to actually sell some things, like my gold and some furniture. (Participant 11)

From one perspective, a respondent who was aged 27, single and ran a supermarket explained that her family supported her to fund her business:

I was encouraged by my family, my mum and dad to actually start a business on my own and have a proper income, but we did not have enough funds for it the business] so we had to borrow money from friends and some families we know to start the business. (Participant 19)

It is clear from the interview data that the participants had to carefully consider problems regarding funding and financial resources, which persisted as their businesses progressed. The findings reveal an overlap between the motherhood (family and household context) and money (funding) facets of the $5 \mathrm{M}$ model as indicated by Brush et al. (2009).

\subsubsection{Safety and Mobility (Macro Factors)}

The participants were asked how they thought the following mobile services could help them: mobile learning; mobile commerce; mobile banking; mobile money; mobile marketing; and other mobile services, such as Skype, WhatsApp and Viber. They explained that these services would support them in relation to mobility issues, communication, and networking with clients and suppliers. One participant, who was aged 33, married and owned a retail outlet, stated: 
I would not have to go out as much and my family and my husband would support me, as they would know that I do not have to go out as much and I am still earning a reasonable income from my business. (Participant 9)

The results of the data analysis confirm the relationship between motherhood (family and household support) and the macro (safety and mobility) facets with reference to the $5 \mathrm{M}$ model (Brush et al., 2009). The participants also explained that mobility and increased security are major benefits associated with using mobile applications to run a successful business. This indicates a link between the mobile technology, macro environment and management facets. All participants agreed that women in Iraq face major challenges with regard to personal security and mobility; the participants indicated that if women entrepreneurs were able to use mobile applications effectively to communicate with stakeholders, these problems would be partly solved. The participants also indicated that doing business via smartphone applications would help to reduce conflict in the family around leaving their homes to go to their business premises. This indicates a link between the mobile technology and motherhood facets which extends the $5 \mathrm{M}$ model. One participant, who was aged 35 , married with four children and owned a retail outlet, stated:

Mobility is an important aspect for us, as we can use it to reduce the amount of time we are outside, which also helps in keeping a work-life balance and reduces family conflicts, as we still have children to look after. (Participant 4)

However, some participants highlighted that although the use of mobile applications could reduce some risks to personal safety, there are also security issues involved in using a smartphone and mobile applications. These include the possibility of losing the mobile device, theft of personal and business information, and harassment over the phone or online. However, the participants were less concerned about security when using a smartphone and applications than about personal safety when running a business outside their homes. One respondent, who was aged 30 , married and owned a retail outlet, stated:

There is another issue, which is the security of the mobile device in terms of storing on my personal and business information. (Participant 18)

The women entrepreneurs explained that using smartphones reduces the need for face-to-face interaction. These were two fundamental benefits of integrating smartphones and applications into a business. Some participants explained that for certain types of businesses (such as pharmacies), it may not be feasible for a woman to run such business entirely by using mobile applications but taking a hybrid approach, similar to bricks and mortar in the marketing literature.

\subsubsection{Personal Security (Macro Factors)}

When asked about other challenges they experience as women entrepreneurs, many participants explained that the political situation and personal safety concerns affected them and their business growth in various ways. They stated that they did not feel safe when they were at their business premises. One participant, who was aged 30, married, educated to bachelor's degree level and owned a retail outlet, stated:

For a female entrepreneur, the threats are doubled as we have to worry about the unstable political situation in the country threatening the safety of females and the harassment of females in particular, in particular those who run a business. (Participant 18)

Personal safety when running a business was a major concern for the women and their families. This shows a strong link between the motherhood and macro environment facets of the $5 \mathrm{M}$ model as indicated by Brush et al. (2009). One participant, who was aged 26, single, educated to bachelor's degree level and owned a wedding decor business, stated:

The older females have more obstacles because the husband is usually in control, so they actually have to balance their work and life in terms of timing and everything else. However, for a single female, it is easier and usually the family is supportive because they do understand that we need to go out and we need to earn money and becoming independent as well and then, which is not the case for a married woman, unfortunately in addition there are obstacles related to the physical security. (Participant 17)

Another participant, who was aged 42 , single, educated to bachelor's degree level and owned a supermarket, stated:

You have all the family members trying to protect you and you have the society which is not very supportive for a female staying in a shop and staying in the business for 10 to $12 \mathrm{~h}$ a day trying to sell different types of products to different customers from different age groups and different genders. (Participant 15). 
Another participant, who was aged 45, a widow with five children, educated to diploma level and owned a catering business, stated:

Well, years ago, it was much safer for a female to start a new business and it was much easier as well nowadays we face the fears in terms of finance and in terms of our security and safety ... sometimes we come across a number of challenges which you do not even account for at the beginning of the business and in general. (Participant 12)

Because of these concerns, many of the participants were always accompanied by a family member when running their business. This was especially the case for the single women. The physical threat was not limited to the insecure situation in Iraq but included sexual harassment. The above statements show a link between the macro environment, motherhood and the market facets of the model.

\subsubsection{Cultural, Societal and Family Restrictions (Macro Factors and Motherhood)}

The interview data revealed that cultural restrictions on women are embedded in Iraqi society. For example, one participant, who was aged 26 and married, stated:

Women are supposed to dress and speak and deal with others in the society in a very formal and restrictive way, and it is different from what we may have in any other country. Even in other Arab countries with the same religion, you would find that women are more independent; they kind of have more freedom in terms of how to operate the business. (Participant 10)

Interestingly, the level of restriction differed according to the participant's marital status. For women who were single, their parents were supportive and encouraged them to start and run a business. A participant who was single, aged 20 and owned a wedding decor business stated:

The culture is unlikely to change. However, we can have other options that can actually help us by making our life easier when we are running a business. (Participant 20)

Another single respondent, who was aged 29, educated to diploma level and owned a fashion retail business, stated:

I am still at a young age so it gets hard sometimes, but even with that the family is very helpful and very supportive. (Participant 21)
From one perspective, participants who were married mentioned a lack of support from family and pressure to balance their responsibilities. In addition, concerns about personal safety have led to an increase in social restrictions on both single and married women. A married participant who was aged 42 and owned a designer warehouse stated:

It is mainly the culture that is generally restricting for women and the unstable economic situation in the country. (Participant 7)

Another married respondent, who was aged 42 and ran a training centre, stated:

The gender inequality in the country is extremely high and it is hard, not just me, even other females that do not even run the business ... so many restrictions are happening on and it seems to be getting worse, especially for those who are married, as we have to balance this with marriage. (Participant 5)

This was elaborated on by another married respondent, who was aged 31 and owned a retail outlet:

It is very challenging and it requires many skills and when it comes to these skills because women stay at home most of the time and they do not have the ability to or freedom to go out get to know people as much as men do. We are very restricted and when we start a business, there is a moral issue. (Participant 6)

The above quotes reveal a strong link between the motherhood, management, macro environment and market facets which confirms the findings of Brush et al. (2009) with reference to the $5 \mathrm{M}$ model, emphasising the significant role motherhood plays as an intermediator of the other facets. Discussing restrictions on married women entrepreneurs, a single respondent who was aged 28 and owned a pharmacy stated:

Women who are married face stronger obstacles and the balance between their husbands and children and their business becomes sometimes impossible, as they need to serve them and they need to be in the business too. (Participant 30)

\subsubsection{The regulatory environment (Meso Factors)}

Despite the exitance of civil laws that are intended to support businesses in Iraq and that men and women have equal 
ownership rights to property, the regulatory environment in the country is still not supportive enough for female entrepreneurs. For examples, the grants or incentives are available to investors come mainly in the form of tax and customs breaks and exemptions rather than offering more encouraging incentives. Furthermore, the regulatory environment in terms of doing business in Iraq is based on generic rules and regulations rather than accounting for the specific issues female entrepreneurs in the country usually face. The participants emphasised that the situation is complicated by the lack of laws and regulations to support them as entrepreneurs or protect them from harassment. Furthermore, no policies or laws exist in the country to protect their businesses. The participants explained that it is necessary to recognise that women constitute a large segment of the population and that over the past decade there has been a significant increase in the number of women who are the only breadwinners in the family (that is, the number of widows). Therefore, they wanted laws and policies that reflect this. One participant, who was aged 34, married with two children and owned a nursery, stated:

The government should know that half of the Iraqi population is made up of women. In recent years, we have continued to suffer from a setback in our economic situation. If they can help us to become successful entrepreneurs and help other women and support them to start new ventures and have the right laws to accommodate this, we will be able to overcome the economic setback we have now much more quickly. (Participant 1)

This shows a link between the meso environment, market and money facets of the $5 \mathrm{M}$ model. Another respondent, who was aged 29, single, educated to diploma level and owned a fashion retail business, agreed. She stated:

In terms of their personal life as well business, women are not supported by the government and they are not supported by law they do have a sort of different obstacles at different levels. I would say that the problem starts with the policies. (Participant 21)

\subsubsection{Entrepreneurship Education and Training (Management and Market)}

The participants indicated that no courses on entrepreneurship are tailored to their needs. Most of the courses on offer are generic, with the objective of improving general skills; they are not aimed at women who are running a business. The participants stated that their main option for learning how to run a company was to complete an undergraduate degree in business, which is time-consuming. According to the participants, the courses should contain up-to-date information about how to run a successful business in the Iraqi market or in specific sectors. The participants highlighted the importance of understanding business concepts and functions. In addition, the participants indicated that there was a lack of understanding of how to evaluate the opportunities in the market and whether they have potential. The participants indicated that education and training on evaluating market opportunities would be helpful. This indicates a clear relationship between the management (human capital) and market (identifying possible market opportunities, segments and target audiences) facets which confirms the findings in Brush et al's (2009) study.

\subsubsection{Access to Supporting Technology (Technology)}

The women entrepreneurs were aware of various business-related technologies, such as mobile applications, mobile social media, mobile payments and mobile commerce more broadly. Furthermore, all participants were aware of the significant impact of technology on their business. However, despite the importance of these technologies, they all stated that there is a general lack of awareness about their availability. One participant stated:

The only technological device which is very widely used is the smartphone and until now, we mainly use it to socialise. (Participant 6)

This shows a link between mobile technology and market opportunities as socialising/ networking is an important element for finding new market opportunities. All the respondents highlighted the need to use technologies, such as mobile devices, that can support them to expand their businesses further.

All the respondents thought that if the prices of smartphones and mobile Internet use were reduced and network connections were strengthened, they would be more likely to use mobile applications to overcome challenges they face as entrepreneurs in Iraq. One participant, who was aged 42 , married with two children and owned a training centre, stated:

If the network connection was better, I would also use the new applications and contact my clients for free. Internet prices are generally high, so I do not use them [applications] a lot at the moment. (Participant 5) 
Another respondent, who was aged 42, married with four children, educated with master's degree, and owned a designer warehouse, also mentioned the quality of the network connection. She stated:

One of the main critical issues associated with the use of smartphones is the network of course as we do not have a strong network connection which is a major issue (Participant 7).

The strength of the network itself was identified as another constraint. Low network strength prevented the participants from using VoIP applications, which are supposed to be less costly than ordinary calls and text messages.

\subsection{How Mobile Applications Can Support Women Entrepreneurs}

All the respondents agreed that using the various mobile services available through mobile devices could support them to run a business. However, the following services are not yet fully available in Iraq: mobile money, mobile commerce, mobile banking, and mobile learning. One participant stated:

Yes, I am aware of how women entrepreneurs use smartphones in other countries, for example in Jordan and from what I hear, it has been a very successful experience for them ... I think using the latest mobile services available on smartphones will make my job a lot easier. (Participant 7)

The participants thought that mobile devices had great potential to minimise the effects of many obstacles they face. For example, a participant who was aged 35 , married with four children and owned a retail outlet stated:

I do not think mobile banking will work in Iraq, because we will need the infrastructure as well as the collaboration between the government and the banks, but I think we can really work if mobile money is available so we have companies like Western Union MoneyGram and many others ... and it may work really well in terms of m-commerce, we can use mobile apps and we can build a mobile site and reach more customers. (Participant 4)

They explained that although not every woman in Iraq uses a mobile device, it is easy to learn how to use one. They agreed that at the time of the interviews, they used smartphones and applications mainly for social reasons rather than for business. The next subsections show how mobile technology (including smartphones and mobile applications) link to each of the challenges identified as part of the facets in our model and how they can be used to overcome these challenges.

\subsubsection{Improved Communication}

One of the main benefits of using mobile applications is that women entrepreneurs can communicate more frequently and effectively with clients, without the need for face-to-face interaction. This increases their chances of not only finding new and/or hard-to-reach market segments, and thereby demonstrating the intersections between mobile technology and marketing. For example, one participant stated:

We can advertise on mobile social media, which many people here can access, and possibly they can pay on mobile. I can deliver the orders, this will help me in terms of mobility so at least I will not have to be physically present in the business and leave my house for such long hours. (Participant 4)

In addition, the participants explained that using mobile applications enables them to contact their customers when it is convenient and, in many cases, more quickly than would be possible by using traditional marketing communications. Some participants explained that using mobile applications also helps them to communicate more effectively with suppliers and other contacts who use smartphones. Many of the participants explained that they use VoIP services, such as Viber, WhatsApp, and Skype. One participant, who was aged 40, married with three children and owned a supermarket, stated:

I started using it [the smartphone] for the business just to communicate with some of the female customers, maybe send them some updates on our offers. Smartphones can enhance how the business operates. There are the different mobile applications like WhatsApp and Viber that we can actually use, and they can all help to market the business. (Participant 14)

Some participants also explained that the increased connection and communication that mobile applications provide are helpful for identifying marketing and growth opportunities for the business. This method of communication does not contradict the cultural norms and family conditions which helps to overcome some of the challenges related to motherhood and macro environment. 


\subsubsection{Mobile Learning for Education and Training}

Research participants indicated that if mobile learning services were made available in Iraq, they can be used to learn about the fundamentals of running a business and the range of benefits accruing from this. One participant, who was aged 29, single, educated to diploma level and owned a fashion retail business, stated:

Providing training courses using smartphone applications is important so we are very used to the idea of using a smartphone for personal use but when it comes to business, it needs to be more structured. Training is definitely required, and I think convincing the government that we do have the capabilities to run the business successfully is important. (Participant 21)

Another respondent stated:

We do not have to do a whole university degree in business studies. We can just go for a short course, maybe two to six months, to learn how to use a smartphone properly for the business. (Participant 7)

Five of the participants explained that they would be interested in using their smartphones to access courses and read materials and updates related to entrepreneurship (through a mobile application); however, such services were not yet available to them. This shows the relationship between mobile technology and management facets in our proposed model.

\subsubsection{Reaching Customers Through Mobile Social Media}

One of the greatest benefits of using mobile applications is the use of social media for marketing - i.e., social media marketing. This was frequently mentioned by the participants, with a specific focus on Facebook and Instagram. From the perspective of these women, the core benefit of relationship marketing, i.e., the ability to market a business and build a strong customer base. One participant, who was aged 30, married and owned a retail outlet, stated:

There are many options here, for example mobile marketing, mobile social media, mobile commerce, and mobile banking, as well and more importantly even, mobile money. (Participant 18)

Another respondent, who was aged 26, single and owned a wedding decor business, stated:

It can be a great advantage for us as well as for our clients, as we can use different applications as a way of marketing. We currently do not use social media but I know that many people use social media many times during the day to check updates. (Participant 17)
While all the participants used social media for personal purposes, not all of them used it for business purposes. Some participants mentioned that they receive orders through social media platforms. In fact, some participants thought that a presence on social media could replace business websites and even the presence of a physical store if mobile payments were enabled in Iraq. The use of mobile social media is part of the services small businesses can use to reach out to customers, which confirms the link between mobile technology and the meso environment facets.

\subsubsection{Business Mobile Applications}

Many participants showed an interest in developing a mobile app that could be used, alongside marketing on mobile social media, as a successful alternative to developing a website. The participants explained that since the use of mobile devises exceeds the use of computers in Iraq, this may be a good alternative. However, for this to work, there is a need for developers who are experts in mobile applications for business, which is currently lacking in the country. More importantly, participants highlighted the need to enable mobile payment services so that business mobile applications can work successfully. The findings revealed a link between the mobile technology and money facets in our proposed model. One participant, who was aged 35 , single and owned a catering business, explained the benefits:

The use of mobile applications for business can be a wonderful solution and we can use it to sell products and reach many customers anytime and anywhere in the country. (Participant 13)

Another participant, who was aged 42, single and owned a supermarket, added:

I think it is a very good tool for increasing communication with our customers and with all suppliers. (Participant 15)

When probed further, some participants explained that using mobile banking was rather complicated, as Iraqi women entrepreneurs generally do not trust banks and use cash for most financial transactions. They believed that using mobile money applications would make it easier to manage business finances.

\section{Discussion}

The ongoing COVID-19 pandemic has been a breeding ground for fast-tracked research papers across numerous journals in the past year - from medical research to social sciences and humanities. Despite that the data for this study was collected prior to the COVID-19 crisis, the study would have implications as the world strives to build back better in a post-crisis environment. Existing COVID-19 related research that have some relevance for this study include 
Campos-Castillo and Laestadius (2020) and Choudrie et al. (2021) which touch upon the digital divide and how to bridge it, respectively. Similarly, Yildirim and Eslen-Ziya (2021) investigated the impact on working conditions during the lockdown, Reichelt et al. (2021), and Zheng and Walsham, (2021) focused on gender inequality. Collectively, these studies have highlighted some areas that are relevant to ensuring the bridging of inequalities that have been accentuated by the current health crisis. This is also particularly prevalent in a context that exhibits patriarchal tendencies. It is our view that effective and well-targeted and supported smartphone use and deployment would not only improve the working conditions of women entrepreneurs, but also help them "build back better" after the current COVID-19 health crisis and improve marketing activities.

In this research, the economic and non-economic challenges facing women entrepreneurs and the role of smartphone innovations in overcoming these challenges and developing strong marketing strategies were investigated. More specifically, the research attempts to answer the following question: What are the challenges facing women entrepreneurs in post-conflict economies and how can smartphones and mobile applications contribute to overcoming these challenges and enabling marketing through smartphone innovation? This study bridges a gap in ICT4D research by going beyond the outcomes related to economic development, which was the focus of previous research in this field (Chew et al., 2015; Sein et al., 2019). More specifically, by taking a sample of Iraqi women entrepreneurs, the current study investigated the challenges facing women entrepreneurs in a developing country (post-conflict region) and the role of mobile technology in overcoming those challenges. It did so through the lens of the $5 \mathrm{M}$ model proposed by Brush et al. (2009). Our study enhances scholarly understanding of the relative importance of technology for women's entrepreneurship in Iraq, a country with one of the widest gender gaps in the world. In addition, it proposes innovative ways of using smartphones and mobile applications to reduce the negative effects of these challenges and empower women.

The finding that entrepreneurship is embedded in women's social and family life is aligned with the $5 \mathrm{M}$ model developed by Brush et al. (2009). The study reveals how smartphones and mobile applications can help women entrepreneurs in Iraq overcome the challenges identified in the $5 \mathrm{M}$ model (i.e., management, money, market, meso and macro factors, and motherhood), which is linked to economic, social, and human development for these women. The study reveals the relationships between the different facets of the proposed model and new relationships between the mobile technology facet and the other facets of the model. We developed a multilevel analytical framework on women's use of technology in entrepreneurship in a developing country context. Our findings show that the barriers to women's successful entrepreneurship are complicated and multi-layered, as indicated in Wheadon and Duval-Couetil's (2018) study. However, these barriers can be addressed through an interdisciplinary approach that integrates technology and entrepreneurship. In the new era of advanced mobile technologies, including smartphones and mobile applications, it can be argued that mobile technology is an important element of the environment surrounding women, especially in developing countries, and that it contributes to social capital. Figure 1 shows our extended $5 \mathrm{M}$ model. The results show clear relationships and overlaps between the facets of the proposed model and the central role our new proposed element 'mobile technology' in this model as it is able to overcome many of the non-economic challenges identified as part of the other facets of the model.

Table 3 provides a summary of the results. We grouped the challenges into each of the five facets of the $5 \mathrm{M}$ model proposed by Brush et al. (2009) and the additional facet 'mobile technology'. Our findings show that Iraqi women face economic and non-economic challenges in each of these six facets; they also reveal how women can use smartphones and mobile applications to overcome these challenges. The benefits of using smartphones and mobile services within the context of women's entrepreneurship are in marketing as well as other areas. They can be summarised as follows: enabling communication, networking and reaching different segments of customers; overcoming the challenges associated with restricted mobility; providing a higher level of personal safety; improving financial management; reducing spending; enabling women to allocate more time for family, which helps to reduce conflict; increasing the ease of running various operations within the business and the family; and enabling women's entrepreneurship to be more consistent with the values of society and culture, which may increase acceptance and support of women in business.

The findings of this research showed that mobile technology is another facet of the proposed model and it strongly links to all other facets. Women entrepreneurs in Iraq face major challenges that stem from living in a male-dominated society and being unable to have a voice. Smartphones and mobile applications can help them to overcome many of these barriers by finding innovative solutions that do not push them to be inconsistent with the values of their society (macro environment).

The non-economic challenges identified in this research included a lack of support from family members and from the society as a whole. This is linked to the dominant culture in Iraq and the fact that it is a patriarchal society. These findings are consistent with those of previous studies, which found that Arab women entrepreneurs do not receive the required level of support from their families (Jamali, 2009; Vossenberg, 2013) and that, in general, their culture does 
Fig. 1 Extended $5 \mathrm{M}$ model

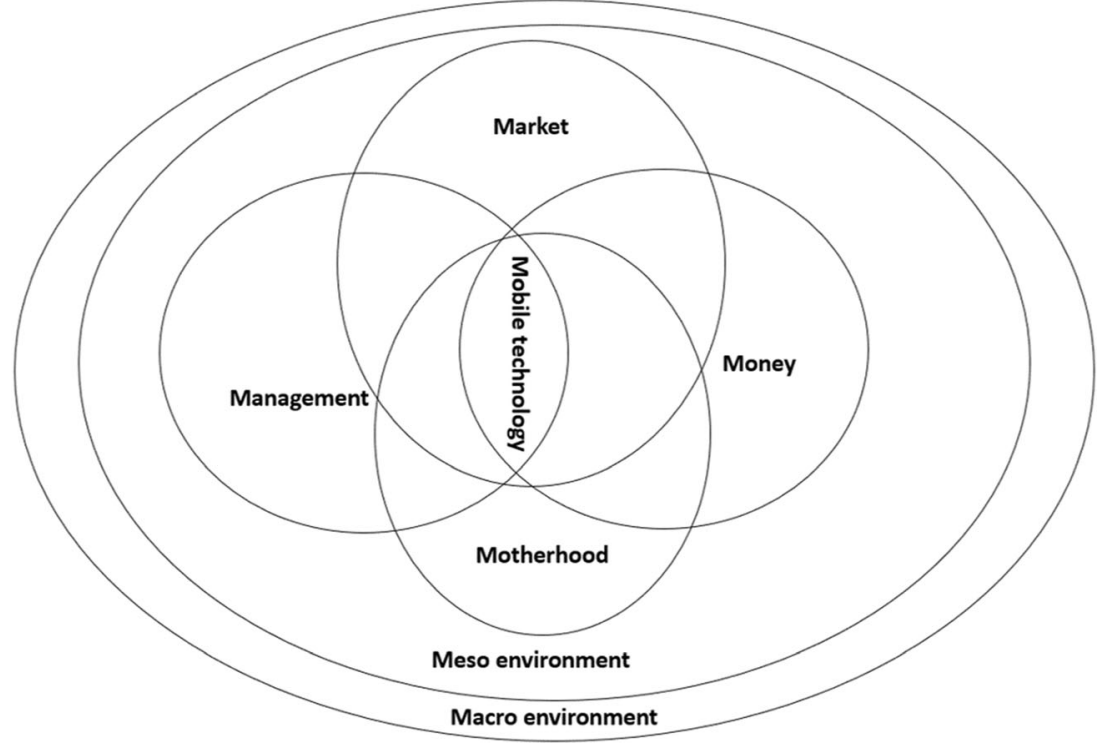

not support them (Ahmad, 2011). Parents support their unmarried daughters to be economically independent and start a business, in addition to protecting them from social and cultural challenges. However, women entrepreneurs who are married with children do not enjoy the same level of support. Indeed, they face restrictions from their husbands and families, who believe that a wife's main priorities should be to be at home and look after the family. These aspects may explain the participants' difficulty in balancing work and family life, since the required level of support was absent internally (within the family) and externally (from society and government bodies). The political situation in Iraq poses a great threat to the safety of these women and restricts their mobility and their interaction with others. Hence, using mobile technology to manage aspects of a business can increase their personal safety and improve their lifestyle. The use of mobile technology helps them to overcome some of the economic and non-economic challenges as part of the motherhood, market and macro environment which shows a link between these facets in our proposed model.

Perhaps one of the most significant benefits of using mobile technology from the perspective of these women is in the areas of marketing and communication as it enables them to network and interact with suppliers and customers indirectly (through mobile-mediated meetings). This reduces the social and cultural pressure associated with face-to-face interactions and increases women's safety. Surprisingly, while previous research has highlighted that smartphones can only complement face-to-face communication for women entrepreneurs (Komunte, 2015), the findings of this research reveal that the participants are interested in using smartphones and some mobile applications as an alternative to technology-mediated meetings. In addition, networking helps women entrepreneurs to reduce costs and reach customers rapidly. The power of communication and of using mobile social media for marketing and increasing customer reach cannot be underestimated. Hence, the use of smartphones and mobile applications can contribute to the social development for these women. Overall, our findings suggest a clear link between the use of smartphones and mobile applications and social capital for women entrepreneurs: these technologies help women to become connected and build social interactions that also benefit their businesses and their own growth.

The findings of this research have shown that mobile applications can enable Iraqi women entrepreneurs to access entrepreneurship training and education to gain management skills that are tailored to them. Smartphones are the most widely available and extensively used technological devices in Iraq, and the women entrepreneurs in this study believed that they were important for running a business. The importance of entrepreneurial education and training in using mobile applications to support a business was found to be important in previous research (Bailur \& Masiero, 2017; Rajan \& Jayashri, 2017; Walsham, 2017). The participants had experience in using smartphones, and they were interested in and open to the idea of using them to run their businesses. However, the results highlight that for smartphones to be used efficiently in business, certain mobile services need to be made available, including mobile money, mobile learning and mobile social media. Since the mobility of these women is restricted, launching training courses and updates on entrepreneurship that they can access through their mobile devices would enable them to obtain information that would help them work more efficiently and gain confidence in what they do. This shows how mobile technology can help to overcome some of the challenges associated with the management facet in our proposed model. 
Table 3 Summary of the results of the research

\begin{tabular}{|c|c|c|c|}
\hline $\begin{array}{l}\text { Facet of the } \\
\text { framework }\end{array}$ & $\begin{array}{l}\text { Challenge facing } \\
\text { women } \\
\text { entrepreneurs }\end{array}$ & $\begin{array}{l}\text { Mobile } \\
\text { application that } \\
\text { can be used to } \\
\text { overcome } \\
\text { challenge }\end{array}$ & $\begin{array}{l}\text { Benefits of these } \\
\text { applications to } \\
\text { women } \\
\text { entrepreneurs }\end{array}$ \\
\hline $\begin{array}{l}\text { Motherhood } \\
\text { Macro/meso } \\
\text { environ- } \\
\text { ment: } \\
\text { Macro } \\
\text { factors }\end{array}$ & $\begin{array}{l}\text { Family barriers } \\
\text { Cultural and } \\
\text { societal } \\
\text { barriers } \\
\text { Lack of personal } \\
\text { security }\end{array}$ & $\begin{array}{l}\text { Calls and text } \\
\text { Mobile social } \\
\text { media }\end{array}$ & $\begin{array}{l}\text { Mobility, higher } \\
\text { level of } \\
\text { personal safety } \\
\text { and avoidance } \\
\text { of cultural and } \\
\text { family barriers } \\
\text { Marketing and } \\
\text { communicat- } \\
\text { ing with } \\
\text { customers }\end{array}$ \\
\hline $\begin{array}{l}\text { Macro/meso } \\
\text { environ- } \\
\text { ment: } \\
\text { Meso } \\
\text { factors }\end{array}$ & $\begin{array}{l}\text { Regional lack of } \\
\text { government } \\
\text { support and } \\
\text { policies }\end{array}$ & $\begin{array}{l}\text { Business mobile } \\
\text { applications }\end{array}$ & $\begin{array}{l}\text { An improved } \\
\text { presentation } \\
\text { for the } \\
\text { business as an } \\
\text { alternative to a } \\
\text { website }\end{array}$ \\
\hline Money & $\begin{array}{l}\text { Lack of funding } \\
\text { and lack of } \\
\text { knowledge in } \\
\text { managing the } \\
\text { business } \\
\text { finance }\end{array}$ & Mobile money & $\begin{array}{l}\text { Managing } \\
\text { finance and } \\
\text { ability to run } \\
\text { the business } \\
\text { remotely. It is } \\
\text { also an } \\
\text { alternative to } \\
\text { mobile } \\
\text { banking }\end{array}$ \\
\hline Management & $\begin{array}{l}\text { Lack of } \\
\text { entrepreneurial } \\
\text { education and } \\
\text { training for } \\
\text { women }\end{array}$ & $\begin{array}{l}\text { Mobile learning } \\
\text { VoIP } \\
\quad \text { applications }\end{array}$ & $\begin{array}{l}\text { Entrepreneurship } \\
\text { education }\end{array}$ \\
\hline Technology & $\begin{array}{l}\text { Lack of access to } \\
\text { ICT }\end{array}$ & $\begin{array}{l}\text { A combination of } \\
\text { mobile } \\
\text { applications }\end{array}$ & $\begin{array}{l}\text { An easy and less } \\
\text { costly way of } \\
\text { communica- } \\
\text { tion in } \\
\text { comparison to } \\
\text { making calls } \\
\text { and texting. }\end{array}$ \\
\hline Market & $\begin{array}{l}\text { Lack of access to } \\
\text { market } \\
\text { opportunities } \\
\text { for women }\end{array}$ & $\begin{array}{l}\text { All of the above } \\
\text { applications } \\
\text { can help to } \\
\text { increase } \\
\text { women } \\
\text { entrepreneurs' } \\
\text { access to } \\
\text { market } \\
\text { opportunities. }\end{array}$ & \\
\hline
\end{tabular}

Using smartphone innovation to overcome the challenges outlined earlier contributes to women entrepreneurs in Iraq running more successful businesses overall and achieving better living standards. Improvements in women's financial situation are reflected in the financial situation of their families and the country as a whole. In addition, using other mobile services - mobile commerce and mobile money - can help these women to carry out business tasks and manage their business finances with more ease and from home. Hence, increasing the availability of mobile money and mobile funding applications would help women entrepreneurs in Iraq to manage the financial aspects of their business and obtain the required funds without needing a bank account. This need is exemplified by the source of funding for most of the women entrepreneurs who we interviewed: selling personal belongings (for married women) or a personal loan from family or family savings (for single women). The mobile services that could reduce the negative effects of the lack of government support (i.e., mobile commerce, mobile banking and mobile money) are not available in Iraq. Therefore, in the case of women entrepreneurs in Iraq, support from the government is required in order to implement these services. This shows that mobile technology can help to overcome some of the challenges associated with the money and meso facets in our proposed model.

\section{Theoretical Contributions}

While previous research has identified and focused on the economic and non-economic challenges faced by women entrepreneurs in Arab countries (e.g., Hattab, 2012; Jamali, 2009; Tlaiss, 2018; Ghouse et al., 2017; Salama 2016), it has not been done from the perspective of the $5 \mathrm{M}$ model proposed by Brush et al. (2009). This research makes several theoretical contributions. The research extends the $5 \mathrm{M}$ model by integrating a new facet - i.e., 'mobile technology' (smartphones and mobile applications), which plays a significant role in the development of women entrepreneurship in a developing country context, Iraq. It develops a more integrated, multilevel analytical model on women in technology entrepreneurship based on extending the $5 \mathrm{M}$ model. It bridges the gap in research on the use of smartphones and mobile applications to support women entrepreneurs through the lens of the $5 \mathrm{M}$ model with a proposition for a sixth " $\mathrm{M}$ " as an intervening variable. In addition, this study is the first study to provide a holistic synthesis of the economic and non-economic challenges facing women entrepreneurs in Iraq and how mobile technologies can help them to overcome these challenges. The study highlights the positive effect of smartphone innovations in being a significant factor determining the success or failure of women's businesses and overcoming some of the other challenges identified in the $5 \mathrm{M}$ model (i.e., management, money, market, meso and macro factors and motherhood). The study bridges the gap in research on the use of mobile technology (smartphones and mobile applications) to support women entrepreneurs through the lens of the $5 \mathrm{M}$ model. 
This study extends knowledge in the field of ICT4D by bridging a gap in research. It moves beyond economic development outcomes to focus on a wider range of development outcomes that women entrepreneurs in developing countries can achieve by using smartphones and mobile applications. This gap was identified in previous studies on ICT4D (Chew et al., 2015; O'Donnell \& Sweetman, 2018; Pandey \& Zheng, 2019; Sein et al., 2019). The research has developed a more integrated, multilevel analytical model for understanding women entrepreneurs' use of smartphones and mobile applications. We investigated how smartphones and mobile applications can play a significant role in the development of women's entrepreneurship in the context of a developing country such as Iraq. The study highlights the positive effects of mobile technology in overcoming challenges identified in the $5 \mathrm{M}$ model (i.e., management, money, market, meso and macro factors, and motherhood) (Brush et al., 2009).

This study contributes to the field of ICT4D by exploring the ways in which smartphones and mobile applications can lead to various development outcomes, including social, human and economic development that can empower women. We found that smartphones and mobile applications help Iraqi women entrepreneurs to overcome cultural, family, and social barriers (macro factors and motherhood) by improving mobile-mediated communication and connecting with customers, which leads to social development. These technologies help women entrepreneurs to interact with their internal and external environments in innovative ways that do not contradict with their culture. In addition, smartphones and mobile applications help women to overcome the lack of entrepreneurial education and training in Iraq (management skills and education) and increase their knowledge in various aspects of business. Moreover, these technologies help women entrepreneurs achieve a decent standard of living and potentially an easier life, which leads to human development outcomes. Furthermore, smartphones and mobile applications can help women to overcome other challenges, including lack of funding (money) and barriers to accessing the market (market). Thus, these technologies contribute towards economic development for these women.

Chew et al. (2015) called for more research and establishing theoretical and empirical links between mobile-phone communications and social capital in the area of ICT4D. In addition to the development outcomes revealed in this research, our findings suggest a clear link between the use of smartphones and mobile applications and social capital for women entrepreneurs: because these technologies help women to become connected without having to go against the cultural norms in their country, women who use them are more likely to obtain emotional and psychological support from their family and society. Mobile technologies also help them to maintain social capital by developing networks beyond their family and friends. Our theoretical framework shows how using smartphones can help women entrepreneurs to build social capital, which is an important contribution to the area of ICT4D.

\section{Managerial Implications}

This study was an initial exploration of the potential development outcomes for women entrepreneurs using smartphones and mobile applications. However, the analysis suggests that it is possible to use smartphones and mobile applications not only to improve these women's financial situation, business management and connecting with customers, but also to improve their social lives and become more educated and informed. Hence, government bodies and policymakers should work with mobile companies to set suitable tariffs and packages in order to reduce the cost of smartphones and the mobile Internet for Iraqi women entrepreneurs. This approach has been used in other parts of the Middle East, such as the United Arab Emirates (Madichie \& Al Athmay, 2013).

Government support is required to enable the successful implementation of the mobile services that we have identified as important for women's entrepreneurship in Iraq: mobile marketing, mobile banking, mobile money, mobile commerce (i.e., m-commerce), and mobile learning. Some of these applications are not available or supported in Iraq. Hence, governments and policy makers should collaborate with the relevant organisations and companies, such as banks, financial services providers, training institutions and mobile companies. Mobile money applications can make payments and business finances easier to manage. Moreover, business support programmes can be initiated, in addition to financial consultation services, to encourage and enable Iraqi women to start and run a successful business. It is important that the appropriate laws, regulations, policies, and financial support are in place to protect and support Iraqi women entrepreneurs and their businesses. This will increase the success of women entrepreneurs and promote gender equality.

Training programmes and campaigns should be launched to raise awareness of the importance of using smartphones in the context of entrepreneurship and communication. These training programmes can introduce women to new and innovative ways to use smartphones and mobile applications to exploit opportunities to run a successful business, be sociable and gain education in business and management. These programmes can be run in collaboration with mobile companies and mobile application developers to cater for these women's needs and preferences.

Although participants in this study considered smartphones and mobile applications to be a safer way to manage their businesses remotely, they were still concerned about their safety while using this technology. Hence, it is crucial to safeguard women by introducing an effective legislative 
framework on harassment (over the phone and online) and on secure mobile payments and mobile banking. Data privacy and security are major concerns for online users, including those who use online platforms such as Facebook, Twitter and Google. In addition, the ethical and security dimensions of using online and mobile platforms is becoming more of a concern for these women.

Taking this from a crisis perspective, the COVID-19 pandemic represents an opportunity for female entrepreneurs who know how to pivot and capitalise on it. Unemployed, some women in MENA have established businesses in the social and solidarity economy or responded to consumer demand for products such as masks. Using ICTs illustrates both the limitations of and opportunities for ICT use. COVID-19 has caused a major digital transformation with people across the globe depending on ICTs for different purposes. Hence, investigating how smartphones can offer meaningful services that help businesses cut costs, increase revenue, expand reach, and improve mobility is even more significant with the emergence of the pandemic. Additionally, smartphones facilitate the growth of social and business networks that equip women entrepreneurs with the knowledge necessary to achieve emancipation.

\section{Limitations and Suggestions for Future Research}

Although this research provides important theoretical contributions and practical implications, it has a number of limitations that can be addressed in future research. Our study focused on smartphone innovations as this is the most widely used technology in the country. However, in line with earlier research (e.g. Ameen et al., 2021a, b), we recommend that future research can focus on the integration of cutting-edge technologies such as artificial intelligence (AI)-enabled chatbots, virtual reality and augmented reality which can be integrated in mobile applications and investigate how these technologies can be used creatively by women entrepreneurs in post pandemics. The participants were selected using purposive sampling in Iraq. Using a different sampling technique and a wider range of participants and more geographically diverse businesses in other post-conflict economies may have brought more issues to light. Future studies could include women from different backgrounds with different education levels and compare the findings with those of this research. This may highlight further steps that government bodies and mobile companies can take to support women entrepreneurs in Iraq. The focus of this research was on women entrepreneurs who had been in business for at least one year. Considering women who were intending to start a business may have provided additional insights into potential barriers attributable to the elements in the $5 \mathrm{M}$ model and how smartphones and mobile applications can help them to exploit more opportunities. Future studies can focus on this group of women entrepreneurs.

Future studies can build on the findings of our research and conduct quantitative studies that collect data from a larger sample of women entrepreneurs in different post-conflict economies, in a cross-national context. Finally, future studies can collect data during and post the COVID-19 global pandemic to study the changes in how women entrepreneurs adopt, use and exploit smartphone innovations in developing countries and post-conflict regions.

\section{Conclusions}

Drawing upon the $5 \mathrm{M}$ model (management, money, market, meso and macro factors and motherhood), this study analysed the role of smartphones and mobile applications in overcoming barriers to entrepreneurial development with a particular focus on women. The study argued, and provided evidence to demonstrate how smartphones and mobile applications have enabled communication and networking among women entrepreneurs, and thereby made it possible for this group to not only overcome the challenges associated with restricted mobility, but also provided them with a higher level of personal safety, improved financial management, quality time for family and other attributes that are societally accepted norms in developing world contexts such as Iraq. Smartphones and mobile applications can help women entrepreneurs by enabling communication and networking; overcoming the economic and non-economic challenges associated with restricted mobility; providing a higher level of personal safety; improving financial management; reducing spending; enabling women to allocate more time for family, which helps to reduce conflict; increasing the ease of running various operations within the business and the family; and enabling women's entrepreneurship to be more consistent with the values of society and culture. Consequently, it is demonstrated that the use, adoption and deployment of smartphone and mobile applications for business purposes have been found to increase the ease of running various operations within the business and the family, as well as enabling women's entrepreneurship to demonstrate their contribution to both business and societal development. Overall, our findings show that smartphones and mobile applications lead to economic, social and human development outcomes for women entrepreneurs. These findings do not offer theoretical contributions only, but also managerial and policy intervention, and especially so in times of crisis such as the ongoing COVID-19 pandemic. 


\section{References}

Ahmad, S. (2011). Evidence of the characteristics of women entrepreneurs in the Kingdom of Saudi Arabia. International Journal of Gender and Entrepreneurship, 3(2), 123-143.

Akwo, F., Alibhai, S., Appaya, S., \& Coleman, R. (2020). In Ethiopia, prototyping a mobile app to support women entrepreneurs facing the pandemic. Accessed 28 July 2021. https://blogs.worldbank.org/ digital-development/ethiopia-prototyping-mobile-app-supportwomen-entrepreneurs-facing-pandemic.

Albashrawi, M., Kartal, H., Oztekin, A., \& Motiwalla, L. (2019). Selfreported and computer-recorded experience in mobile banking: A multi-phase path analytic approach. Information Systems Frontiers, 21(4), 773-790.

Albashrawi, M., \& Motiwalla, L. (2019). Privacy and personalization in continued usage intention of mobile banking: An integrative perspective. Information Systems Frontiers, 21(5), 1031-1043

Aldairany, S., Omar, R., \& Quoquab, F. (2018). Systematic review: entrepreneurship in conflict and post conflict. Journal of Entrepreneurship in Emerging Economies, 10(2), 361-383.

Al-Dajani, H., \& Marlow, S. (2010). Impact of women's home-based enterprise on family dynamics, evidence from Jordan. International Small Business Journal, 28(5), 470-486.

Alderete, M. V. (2017). Mobile broadband, a key enabling technology for entrepreneurship? Journal of Small Business Management, 55(2), 254-269.

Alhabidi, M. (2013). Saudi women entrepreneur overcoming barriers in ALKhober. Ph.D. dissertation, Arizona State University, AZ

Ameen, N., Hosany, S., \& Tarhini, A. (2021). Consumer interaction with cutting-edge technologies: Implications for future research. Computers in Human Behavior, 120, 106761.

Ameen, N., Tarhini, A., Reppel, A., \& Anand, A. (2021). Customer experiences in the age of artificial intelligence. Computers in Human Behavior, 114, 106548.

Ameen, N., \& Willis, R. (2016). The use of mobile phones to support women's entrepreneurship in the Arab Countries. International Journal of Gender and Entrepreneurship, 8(4), 424-445.

Ameen, N., \& Willis, R. (2018). A generalized model for smartphone adoption and use in an Arab context, a cross-country comparison. Information Systems Management, 35(3), 254-274.

Ameen, N., \& Willis, R. (2018b). Towards closing the gender gap in Iraq, understanding gender differences in smartphone adoption and use. Information Technology for Development, 1-26. https://doi.org/10. 1080/02681102.2018.1454877

Ameen, N., Willis, R., Abdullah, M. N., \& Shah, M. (2018). Towards the successful integration of e-learning systems in higher education in Iraq, a student perspective. British Journal of Educational Technology. https://doi.org/10.1111/bjet.12651.

Ameen, N., Willis, R., \& Shah, M. H. (2018). An examination of the gender gap in smartphone adoption and use in Arab Countries, a cross-national study. Computers in Human Behavior, 89, 148-162.

Anand, A., Vessal, S., Rathi, K., \& Ameen, N. (2021). Show me your mobile and I will tell you who you are: Forecasting consumer compassion and altruism behaviour through smartphone type and usage. Journal of Retailing and Consumer Studies, 63, 102657. https://doi. $\operatorname{org} / 10.1016 /$ j.jretconser.2021.102657.

Bailur, S., \& Masiero, S. (2017). Women's income generation through mobile internet, a study of focus group data from Ghana, Kenya, and Uganda. Gender, Technology and Development, 21(2), 77-98.

Bailur, S., Masiero, S., \& Tacchi, J. (2018). Gender, mobile, and mobile internet| gender, mobile, and development: the theory and practice of empowerment-Introduction. Information Technologies \& International Development, 14, 9-15.
Baro, E. E., \& Endouware, E. (2013). The effects of mobile phone on the socio-economic life of the rural dwellers in the Niger Delta region of Nigeria. Information Technology for Development, 19(3), 249-263.

Bastian, B. L., Sidani, Y. M., \& El Amine, Y. (2018). Women entrepreneurship in the Middle East and North Africa, A review of knowledge areas and research gaps. Gender in Management, An International Journal, 33(1), 14-29.

Bates, T., Jackson, W. E., \& Johnson, J. H. (2007). Introduction, advancing research on minority entrepreneurship. Annals of the American Academy of Political and Social Science, 613, 10-17.

Baur, R. (2018). Redefining entrepreneurship in Iraq. Accessed 28 July 2021. https://www.tbd.community/en/a/entrepreneurship-iraqinterview-the-station

Berger, E. S., \& Kuckertz, A. (2016). Female entrepreneurship in startup ecosystems worldwide. Journal of Business Research, 69(11), $5163-5168$.

Bhavnani, A., Chiu, R. W. W., Janakiram, S., Silarszky, P., \& Bhatia, D. (2008). The role of mobile phones in sustainable rural poverty reduction. Retrieved on May 29 2021. https://documents1.worldbank. org/curated/en/644271468315541419/pdf/ 446780WP0Box321bile1Phones01PUBLIC1.pdf

Boateng, A. (2017). African female entrepreneurship, merging profit and social motives for the greater good. Springer.

Brück, T., Naudé, W., \& Verwimp, P. (2013). Business under fire: Entrepreneurship and violent conflict in developing countries. Journal of Conflict Resolution, 57(1), 3-19.

Brush, C. G., \& Cooper, S. Y. (2012). Female entrepreneurship and economic development, an international perspective. Entrepreneurship \& Regional Development, 24(2), 1-6.

Brush, C. G., De Bruin, A., \& Welter, F. (2009). A gender-aware framework for women's entrepreneurship. International Journal of Gender and Entrepreneurship, 1(1), 8-24.

Campos-Castillo, C., \& Laestadius, L. I. (2020). Racial and ethnic digital divides in posting COVID-19 content on social media among US adults: secondary survey analysis. Journal of medical Internet research, 22(7), e20472

Carter, S., Anderson, S., \& Shaw, E. (2001). Women's Business Ownership, A Review of the Academic, Popular and Internet Literature. Discussion paper, DTI Small Business Service Research Report

Ceasefire Centre. (2015). Ceasefire project, protecting the human rights of vulnerable civilians in Iraq. Accessed 15 Sept 2018. http:// minorityrights.org/what-we-do/ceasefire-project/

Charmaz, K. (2014). Grounded theory in global perspective: Reviews by international researchers. Qualitative Inquiry, 20(9), 1074-1084.

Chew, H. E., Ilavarasan, V. P., \& Levy, M. R. (2015). Mattering matters: Agency, empowerment, and mobile phone use by female microentrepreneurs. Information Technology for Development, 21(4), 523-542.

Choudrie, J., Obuekwe, C., \& Zamani, E. (2021). Bridging the digital divide in ethnic minority older adults: an organisational qualitative study. Information Systems Frontiers. https://doi.org/10.1007/ s10796-021-10126-8.

Choudrie, J., Pheeraphuttranghkoon, S., \& Davari, S. (2020). The digital divide and older adult population adoption, use and diffusion of mobile phones: A quantitative study. Information Systems Frontiers, 22(3), 673-695.

Corbin, J., \& Strauss, A. (2008). Basics of qualitative research: Techniques and procedures for developing grounded theory (3rd ed.). Sage.

Crittenden, V. L., Crittenden, W. F., \& Ajjan, H. (2019). Empowering women micro-entrepreneurs in emerging economies: The role of information communications technology. Journal of Business Research, 98, 191-203. 
Davies, I. A., Chambers, L., \& Haugh, H. (2018). Barriers to social enterprise growth. Journal of Small Business Management. https:// doi.org/10.1111/jsbm.12429.

Donner, J., \& Escobari, M. X. (2010). A review of evidence on mobile use by micro and small enterprises in developing countries. Journal of International Development, 22(5), 641-658.

Eisenhardt, K. M., \& Graebner, M. E. (2007). Theory building from cases, opportunities and challenges. Academy of Management Journal, 50(1), 25-32.

Elena-Bucea, A., Cruz-Jesus, F., Oliveira, T., \& Coelho, P. S. (2020). Assessing the role of age, education, gender and income on the digital divide: evidence for the European Union. Information Systems Frontiers, 1-15. https://doi.org/10.1007/s10796-02010012-9

Eufemia, L., Lozano, C., Rodriguez, T., Del Rio, M., Morales-Muñoz, H., Bonatti, M. ... Löhr, K. (2020). Peacebuilding in times of COVID-19: risk-adapted strategies of cooperation and development projects. Zeitschrift für Friedens-und Konfliktforschung, 1-17

Expat Arrivals. (2017). Doing business in Iraq. Accessed 11 Sept 2018. https://www.expatarrivals.com/iraq/doing-business-in-iraq

Faraj, N. (2020). The economic participation of Iraqi women is among the lowest in the world. Accessed 28 July 2021. https://kirkuknow.com/ en/news/63142

Ghahramani, F., \& Wang, J. (2019). Impact of smartphones on quality of life: A health information behavior perspective. Information Systems Frontiers, 22(1), 1-16.

Ghouse, S., McElwee, G., Meaton, J., \& Durrah, O. (2017). Barriers to Rural Women Entrepreneurs in Oman. International Journal of Entrepreneurial Behavior and Research, 23(6), 998-1016

Glaser, B. G., \& Strauss, A. L. (2017). Discovery of grounded theory: Strategies for qualitative research. Routledge

Gomera, W. C., Suhonen, J., Oyelere, S. S., \& Kapinga, A. F. (2019). Mobile technology for record keeping by women entrepreneurs in Tanzania: User requirement assessment. In International Conference on Social Implications of Computers in Developing Countries (pp. 649-659). Springer

Hartmann, H. I. (2001). The unhappy marriage of marxism \& feminism, towards a more progressive union. In Social Stratification, Class, Race, and Gender in Sociological Perspective (pp. Westview, 673680). Ed. D. B. Grusky

Hashem, E. (2015). The impact of ICT investment on human development. International Journal of Management Sciences, Research Academy of Social Sciences, 5(1), 111-124.

Hattab, H. (2012). Towards understanding female entrepreneurship in Middle Eastern and North African countries, a cross-country comparison of female entrepreneurship. Education, Business and Society, Contemporary Middle Eastern Issues, 5(3), 171-186.

Huang, J. Q. (2018). Digital aspirations:'wrong-number'mobile-phone relationships and experimental ethics among women entrepreneurs in rural Bangladesh. Journal of the Royal Anthropological Institute, 24(1), 107-125

Iakovleva, T., Solesvik, M., \& Trifilova., A. (2013). Financial availability and government support for women entrepreneurs in transitional economies, cases of Russia and Ukraine. Journal of Small Business and Enterprise Development, 20(2), 314-340.

International Rescue Committee. (2014) Are We Listening? Acting on Our Commitments to Women and Girls Affected by the Syrian Conflict. International Rescue Committee. Accessed 5 Aug 2018. https://www.peacewomen.org/sites/default/files/irc_womeninsyria report_web_1_0.pdf

Irene, B. N. O. (2019). Technopreneurship: a discursive analysis of the impact of technology on the success of women entrepreneurs in South Africa. Digital Entrepreneurship in Sub-Saharan Africa (pp. 147-173). Palgrave Macmillan.
Ishak, N., \& Bakar, A. (2012). Qualitative data management and analysis using NVivo: An approach used to examine leadership qualities among student leaders. Education Research Journal, 2(3), 94-103.

Jamali, D. (2009). Constraints and opportunities facing women entrepreneurs in developing countries, a relational perspective. Gender in Management, 24(4), 232-251.

Kapinga, A. F., Montero, C. S., \& Mbise, E. R. (2016). Investigating Women Entrepreneurs' Usage of Mobile Technology for Accessing Market Information in Iringa, Tanzania. In Interactive Mobile Communication, Technologies and Learning (IMCL), 2016 International Conference on (pp. 73-77). IEEE

Kapinga, A. F., Suero Montero, C., \& Mbise, E. R. (2019). Mobile marketing application for entrepreneurship development: Codesign with women entrepreneurs in Iringa, Tanzania. The Electronic Journal of Information Systems in Developing Countries, 85(2), 120-173.

Kazemi, F. (2000). Gender, islam, and politics. Social Research, 67(2), 453-474.

Komunte, M. (2015). Usage of mobile technology in women entrepreneurs, a case study of Uganda. African Journal of Information Systems, 7(3), 52-74.

Larsson, C. W., \& Svensson, J. (2018). Mobile phones in the transformation of the informal economy: stories from market women in Kampala, Uganda. Journal of Eastern African Studies, 12(3), 533551

Mackey, K. A. (2012). Mobile phones and gender inequality, can we hear her now? Master's thesis, Georgia State University. Accessed 18 Aug 2018. https://scholarworks.gsu.edu/political science theses/52

Madichie, N. (2011). A preliminary assessment of middle east investments in Sub-Saharan Africa, insights from the mobile telecom sector. Thunderbird International Business Review, 53(1), 79-92.

Madichie, N., \& Al Athmay, A. (2013). An initial assessment of eGovernance and public sector marketing in the UAE. International Journal of Business and Emerging Markets, 5(3), 234-253.

Mahrer, A. R. (1988). Discovery-oriented psychotherapy research: Rationale, aims, and methods. American Psychologist, 43(9), 694 702.

Manolova, T. S., Brush, C. G., Edelman, L. F., \& Elam, A. (2020). Pivoting to stay the course: How women entrepreneurs take advantage of opportunities created by the COVID-19 pandemic. International Small Business Journal, 38(6), 481-491.

Martinez, I., \& Nguyen, T. (2014). Using information and communication technology to support women's entrepreneurship in Central and West Asia.C Asian Development Bank. http://hdl.handle.net/ 11540/595. License: CC BY 3.0 IGO.

Mazawi, A. E. (2002). Educational expansion and the mediation of discontent, the cultural politics of schooling in the Arab States. Discourse, Studies in the Cultural Politics of Education, 23(1), 59-74.

McMillan, J., \& Woodruff, C. (2002). The central role of entrepreneurs in transition economies. Journal of Economic Perspectives, 16(3), 153-170.

Melumad, S., \& Meyer, R. (2020). Full disclosure: How smartphones enhance consumer self-disclosure. Journal of Marketing, 84(3), 28-45.

Neuman, W. L. (1997). Social research methods, qualitative and quantitative approaches. Allyn and Bacon.

Newell, A. (2011). Could cell phones benefit women entrepreneurs in developing countries? Triple Pundit. Accessed 20 Aug 2018. https:// www.triplepundit.com/2011/09/could-cell-phones-benefit-womenentrepreneurs-developing-countries/

Nuseibeh, H. Z., Hevner, A. R., \& Collins, R. W. (2017). What can be controlled: actionable ICT4D in the case of Palestine. Information Technology for Development (pp. 1-34). https://doi.org/10.1080/ 02681102.2017 .1357526 
O’Donnell, A., \& Sweetman, C. (2018). Introduction: Gender, development and ICTs. Gender \& Development, 26(2), 217-229. https:// doi.org/10.1080/13552074.2018.1489952.

Pal, A., \& Herath, T. (2020). The role of mobile payment technology in sustainable and human-centric development: evidence from the post-demonetization period in India. Information Systems Frontiers (pp. 1-25). https://doi.org/10.1007/s10796-020-09982-7

Pal, A., Herath, T., \& Rao, H. R. (2020). Is the convenience worth the risk? An investigation of mobile payment usage. Information Systems Frontiers (pp. 1-21). https://doi.org/10.1007/s10796-02010070-Z

Pandey, P., \& Zheng, Y. (2019). Unpacking empowerment in ICT4D research. In International Conference on Social Implications of Computers in Developing Countries (pp. 83-94). Springer

Pandit, N. (1996). The creation of theory: A recent application of the grounded theory method. The Qualitative Report, 2(4), 1-15.

Patton, M. Q. (2002). Qualitative research and evaluation methods. Sage.

Pergelova, A., Angulo-Ruiz, F., \& Yordanova, D. I. (2018). Gender and international entry mode. International Small Business Journal, $36(6), 662-685$.

Rajan, R., \& Jayashri, G. (2017). Empowering Women through Mobile and Web Based Application Technology. International Journal of Research, (5)9, 41-45

Reichelt, M., Makovi, K., \& Sargsyan, A. (2021). The impact of COVID19 on gender inequality in the labor market and gender-role attitudes. European Societies, 23(1), S228-S245.

Salama, H. (2016). Women entrepreneurship in MENA, an analysis. EcoMENA, Accessed 20 Aug 2018. https://www.ecomena.org/ women-entrepreneurship-in-mena

Sein, M. K., Thapa, D., Hatakka, M., \& Sæbø, Ã. (2019). A holistic perspective on the theoretical foundations for ICT4D research. Information Technology for Development, 25(1), 7-25

Shashidhar, A. (2021). How COVID-19 made micro women entrepreneurs digital savvy. Accessed 28 July 2021. https://www. businesstoday.in/current/corporate/how-covid-19-made-microwomen-entrepreneurs-digital-savvy/story/433920.html

Sinha, S. (2018). Gender digital divide in india: impacting women's participation in the labour market. In Reflecting on India's Development (pp. 293-310). Springer.

Stead, V. (2017). Belonging and women entrepreneurs, Women's navigation of gendered assumptions in entrepreneurial practice. International Small Business Journal, 35(1), 61-77.

Strauss, A. (1990). Basics of qualitative research, grounded theory procedures and techniques. Sage.

Sultana, A. (2012). Patriarchy and women's subordination, a theoretical analysis. Arts Faculty Journal, 4(1), 1-18.

Sutton, J., \& Austin, Z. (2015). Qualitative research: data collection, analysis, and management. The Canadian Journal of Hospital Pharmacy, 68(3), 226-231.

Tahir, R., \& Baradie, M. E. (2019). Behind the veil: the challenges and impediments encountered by women entrepreneurs in the United Arab Emirates. International Journal of Entrepreneurial Venturing, 11(3), 258-282.

Tam, C., Santos, D., \& Oliveira, T. (2020). Exploring the influential factors of continuance intention to use mobile Apps: Extending the expectation confirmation model. Information Systems Frontiers, 22(1), 243-257.

Tlaiss, H. A. (2018). Contextualizing the career success of Arab women entrepreneurs. Entrepreneurship \& Regional Development, 1-16. https://doi.org/10.1080/08985626.2018.1551790
Tlaiss, H. A., \& Kauser, S. (2019). Entrepreneurial leadership, patriarchy, gender, and identity in the Arab world: lebanon in focus. Journal of Small Business Management, 57(2), 517-537.

Trading Economics. (2016). Iraq, population, female (\% of Total). Accessed 10 Aug 2020. https://tradingeconomics.com/iraq/ population-female-percent-of-total-wb-data.html

Uchida, O., Tajima, S., Kajita, Y., Utsu, K., Murakami, Y., \& Yamada, S. (2020). Development and implementation of an ICT-based disaster prevention and mitigation education program for the young generation. Information Systems Frontiers, 1-11. https://doi.org/10.1007/ s10796-020-10082-9

UFM [Union for the Mediterranean]. (2020). Challenge Lab 1: economic impact of COVID-19 on women and girls. Accessed 29 May 2021. https://ufmsecretariat.org/challenge-lab-1-economic-impact-ofcovid-19-on-women-and-girls/

UNDP. (2012). Women's Economic Empowerment, Integrating Women into the Iraqi Economy. UNDP. Accessed 19 Aug 2020. http:// www.undp.org/content/dam/rbas/doc/Women's\%20Empowerment/ Report\%200n\%20Women\%E2\%80\%99s\%20Economic\% 20Empowerment\%20in\%20Iraq,\%20Integrating\%20Women $\%$ 20in\%20the\%20Iraqi\%20Economy-.pdf

Vilardo, V., \& Bittar, S. (2018). Gender Profile-Iraq: A situation analysis on gender equality and women's empowerment in Iraq. Accessed 29 May 2021. https://oxfamilibrary.openrepository.com/bitstream/ handle/10546/620602/rr-gender-profile-iraq-131218-en.pdf

Vossenberg, S. (2013). Women's Entrepreneurship Promotion in Developing Countries, What Explains the Gender Gap in Entrepreneurship and How to Close It? Working paper 2013/08. Maastricht School of Management. Accessed 20 Aug 2018. https:// www.msm.nl/resources/uploads/2014/02/MSM-WP2013-08.pdf

Walsham, G. (2017). ICT4D research: reflections on history and future agenda. Information Technology for Development, 23(1), 18-41.

Ward, L. (2007). Taking care of business. Accessed 20 Aug 2018. http:// www.theguardian.com/money $/ 2007 / \mathrm{mar} / 23 /$ genderissues. worklifebalance

Welsh, D. H., Kaciak, E., \& Shamah, R. (2018). Determinants of women entrepreneurs' firm performance in a hostile environment. Journal of Business Research, 88, 481-491.

Welsh, D. H., Memili, E., Kaciak, E., \& Al Sadoon, A. (2014). Saudi women entrepreneurs: A growing economic segment. Journal of Business Research, 67(5), 758-762.

Wheadon, M., \& Duval-Couetil, N. (2018). Token entrepreneurs, a review of gender, capital, and context in technology entrepreneurship. Entrepreneurship \& Regional Development, 1-29. https://doi.org/ 10.1080/08985626.2018.1551795.

Wolff-Piggott, B., Coleman, J., \& Rivett, U. (2018). The clinic-level perspective on mHealth implementation: a South African case study. Information Technology for Development, 24(3), 532-553.

World Bank. (2016). Women, business and the law 2016. Accessed 22 Aug 2018 . http://pubdocs.worldbank.org/en/ 810421519921949813/Women-Business-and-the-Law-2016.pdf

Yeo, B., \& Grant, D. (2017). Exploring the effects of ICTs, workforce, and gender on capacity utilization. Information Technology for Development, 25(1), 1-29.

Yildirim, T. M., \& Eslen-Ziya, H. (2021). The differential impact of COVID-19 on the work conditions of women and men academics during the lockdown. Gender, Work \& Organization, 28, 243-249.

Zheng, Y., \& Walsham, G. (2021). Inequality of what? An intersectional approach to digital inequality under Covid-19. Information and Organization, 31(1), 100341. 
Publisher's Note Springer Nature remains neutral with regard to jurisdictional claims in published maps and institutional affiliations.

Nisreen Ameen is a Lecturer in Marketing and the Co-Director of the Digital Organisation and Society research centre at Royal Holloway, University of London. Nisreen's research interests include digital marketing, human-computer interaction, consumer behaviour, artificial intelligence (AI)-enabled customers service, security and ethics of retailers use of consumers' data, e-business and technology adoption.

Nnamdi O. Madichie is Research Fellow at the Bloomsbury Institute London. He is also Visiting Professor at both the UNIZIK Business School, Awka, Nigeria, and the Coal City University, Enugu, Nigeria. In addition to being External Examiner at the Liverpool Business School, UK, he is a Fellow of the Chartered Institute of Marketing (FCIM), Fellow of the Chartered Management Institute (FCMI), and Senior Fellow of the Higher Education Academy of England \& Wales (SFHEA). His research straddles broad areas of Marketing \& Entrepreneurship cutting across geographic contexts, notably Africa,
Asia, Europe and the Middle East. He has published extensively (anecdotes, books, book chapters, case studies and refereed journal articles) in these areas. https://orcid.org/0000-0001-8400-5527

Amitabh Anand presently working as Associate Professor for Excelia Business School in France.He has won several awards in research: "Excellence in Peer Review" from South Asian Journal of Human Resources, "Emerging Scholar Award" from organization studies research network at Germany in 2018. For his contribution to teaching he was the only one from Europe to be chosen as the"Top 50 Worlds Best Professor"by Poets and Quants, USA in 2018. He is also part of the Editorial advisory/review board of International Journal of Entrepreneurial Behaviour and Research, Management Decision and Employee Relations, He is presently the review editor for International Studies on Management and Organization. His research works are published in FT 50 journal such as the Journal of Business Venturing and other leading journals such as Computers in Human Behaviour, Journal of Knowledge Management, Personnel Review, Management International etc. 